DOI: $10.20472 / B M .2015 .3 .2 .003$

\title{
CORPORATE DIVERSIFICATION AND BOARD COMPOSITION IN JAPANESE ELECTRONICS CORPORATIONS
}

\section{TAKAHIRO NISHI}

\begin{abstract}
:
I consider the strategic implications of corporate governance by examining the relationship between diversification and board composition, considering both agency theory and the resource-based view of the firm. Many Japanese electronics companies have performed sluggishly and instituted major governance and management reforms. The strategic choice between focus and diversification is the foremost issue for Japanese firms aiming to improve their performance. पThis study uses a multivariate regression model with data from 217 Japanese electronics corporations for the fiscal year 2013 to examine the impact of board composition on decisions regarding corporate diversification. I find that corporate boards encourage corporations to pursue value-generating activities. I also argue that corporate boards can evaluate the quality of resources and allocate rents inside companies, as boards encourage firms to make use of idiosyncratic resources.
\end{abstract}

\section{Keywords:}

Corporate governance, Diversification, Agency Theory, Resource Based-view, Board of Director

JEL Classification: M10, M29

\section{Authors:}

TAKAHIRO NISHI, Meiji University, JAPAN, Email: takahi52@meiji.ac.jp

\section{Citation:}

TAKAHIRO NISHI (2015). Corporate diversification and board composition in Japanese electronics corporations. International Journal of Business and Management, Vol. III(2), pp. 27-44.,

10.20472/BM.2015.3.2.003 


\section{Introduction}

In this study, I examine the relationship between board composition and diversification strategy in Japanese electronic corporations. Many Japanese electronics companies have performed sluggishly and instituted major governance and management reforms. The strategic choice between focus and diversification is the foremost issue for Japanese firms aiming to improve their performance.

Japanese corporate governance used to be characterized by block-shareholding by corporations and financial institutions, in particular, extensive inter-corporate shareholdings, which have kept foreign shareholding ratios low and caused the external control mechanism to cease functioning. This conventional governance model changed after the economic bubble burst in the late-1990s and the block shareholding pattern within Japanese corporations was dismantled. Since then, Japanese corporate shares have been held by intuitional investors who have strong incentives to monitor managers to enhance shareholder value.

Japanese electronics corporations face pressure to move away from conventional strategies and corporate governance systems from changes in the corporate environment brought about by financial and product markets. These companies have instituted major corporate governance reforms to improve shareholder value, though some doubt the effect of corporate boards on strategic management. Japanese companies must arrange business units to generate profits while considering diversification to explore new profit opportunities.

A corporation's diversification strategy is influenced by the board structure and system of corporate governance. Agency theory assumes that financial and other unrelated diversification reinforces the CEO's power and diverges from the owners' interests, thereby creating no value for stockholders. Agency theory also holds that the CEO is a risk-averse agent. When free cash flow is available, the CEO will undertake non-value creating rather than value creating business that may enhance stockholder value. Aligning the interests of stockholders and managers reduces financial and unrelated diversification. To enhance the corporate board's monitoring ability, I propose that the board should have an outsider-dominant composition.

On the other hand, a strategic perspective like the resource-based view of the firm holds that related diversification leads to superior firm performance compared to a focused strategy because the company can explore business opportunities and generate additional return. The resource-based context assumes two types of corporate board composition. In the first, it is composed of insiders because they are motivated to pursue company growth regardless of stockholders' concerns, emphasizing distinctive resources, which are diversified into several business units. In the second configuration, the corporate board is composed of outsiders because the company seeks high-level links with and access to resources in the outside environment

I consider the strategic implications of corporate governance by examining the relationship between diversification and board composition. This study examines the impact of board composition on decisions related to corporate diversification in Japanese electronics corporations. 


\section{Literature review and hypotheses development}

The relationship between corporate governance and diversification is relevant to strategic decisions that improve the value from resource distribution, and merit study. Corporate diversification does not always connect to stockholders' profit, so a conflict of interest between stockholders and other stakeholders may arise. Normally, corporations expand and diversify their business to explore business opportunities in pursuit of sales growth and profitability. However, some stakeholders' goals may go unfulfilled as they have differing interests and types of risk.

In Japan, corporations tend to form reciprocal share holdings in business groups, and the corporate governance system was characterized by cross-shareholdings. Reciprocal shareholdings are a strategy to exclude interventions from outside stockholders. As top management was not concerned with stockholder influence, they focused on insider-oriented management. It is also important for firms to capture value through business relationships rather than distribute dividends to stockholders. A diversification strategy is required to find new growth opportunities and reduce risk, which firms tend to pursue to stabilize the business and enhance managers' wealth.

Foreign institutional investors benefit from the return of stock and dividend distributions, and gain no benefit from sales growth and business relationship formed through cross-shareholdings. As foreign institutional investors appropriate value from financial profits, they motivate managers to diversify when they anticipate growing profit and to avoid excessive growth and diversification strategies irrelevant to enhancing stockholders' value. The diversification goals are assumed to be related to ownership style and the extent to which diversification yields growth or profit. This relationship between ownership style and diversification through a strategic orientation toward growth or profit is best understood through theoretical perspectives developed for corporate governance and strategy, such as agency theory and the resource-based view of the firm.

Agency theory assumes that a conflict between shareholders and management arises when management pursues its own interests. The diverging interests of shareholders and managers could be reflected in different corporate strategy preferences. Shareholders and management are exposed to different risks; shareholders can reduce risk by diversifying their investment portfolio, so they tend to prefer risk-taking activities.

Managers, on the other hand, cannot apply diversification to reduce risk to the same extent that shareholders can (Chen 2009; Jensen 1986, May 1995). Managers devote their efforts to one corporation and engage in human-specific investments that yield no returns from other corporations, while also risking termination if company performance declines. Corporate managers are therefore risk-averse to preserve their position. Additionally, they might further entrench and stabilize their positions by diversifying the company's business such that stockholders cannot intervene and have no influence (Marris 1964).

Corporate diversification reinforces the CEO's power and creates no value for stockholders, hence leading to a divergence from the owners' interests. When free cash flow is available, CEOs will undertake non-value creating businesses rather than value creating businesses that may enhance stockholder value. Aligning the interests of stockholders and managers reduces diversification, especially unrelated and financial diversification.

In this case, institutional owners may be hesitant to support corporate diversification and motivate managers to focus on more profitable business. First, owners can reduce risk through investment 
portfolio diversification, so they prefer that companies avoid diversifying their business. It is more efficient and profitable for a corporation to focus on their primary business. Second, in a diversified corporation, capital investments in low profit ventures would be excessive, creating inefficiency in asset allocation. Third, due to the information asymmetry between owners and managers, owners have difficulty fully understanding the corporate business and qualitatively and quantitatively evaluating corporate value. Therefore:

\section{Hypothesis 1a: There is a negative association between ownership by institutional investors and level of diversification.}

Boards of directors are a device to monitor CEOs and to manage the corporation for the shareholders' benefit. To enhance its monitoring ability, corporate boards are composed of outsiders who have no relationship with the CEO, preventing the CEO from spending free cash flow on non-value generating projects. Agency theory treats the CEO as a risk-avert agent and suggests that a vigilant corporate board can motivate CEOs to focus on enhancing shareholder value, thus aligning their interests with those of the corporation. The alignment of these interests reduces financial and unrelated diversification by enhancing the corporate board's monitoring ability with an outsider-dominant composition.

The Japanese corporate governance system used to be dominated by insiders, and the CEO has a significant amount of power in choosing insiders in the boardroom. This system is sustained by cross-shareholding and stable shareholders, which guarantee stable business management and exclude the influence and intervention of outsiders. Boards predominately composed of insiders or interlocking directors among cross-shareholding corporations do not interfere with corporate management and are not implicitly concerned with other firms' business. However, institutional investors have emerged as shareholders since the late 1990s and have intervened in by sending or proposing directors during shareholders' meetings. Yoshikawa and Phan (2005) showed that corporate nominee directors (dispatched by investors) are associated with lower levels of product diversification. Investors pay attention to board composition and enhance its monitoring ability to protect owners' interests.

\section{Hypothesis 1b: There is a negative association between board independence and level of diversification.}

The resource-based view of the firm argues that sustainable competitive advantage is rooted in a firm's internal resources and capabilities. Unique and firm-specific assets reinforce the company's strength and improve its competitive position. Corporation must build the organization to create capabilities by appropriately allocating internal resources. The resources that generate competitive advantage are composed of value, rarity, inimitability, organization. The combination and interaction among these elements generate sustainable advantage since they are a firm-specific asset that is hard for competitors to imitate. In other words, imitability is created from firm-specific assets that rely on path dependency to accumulate skills and resources. 
According to the resource-based view, corporations diversify toward new businesses that are relevant to existing businesses using similar resources and with similar customers. A diversification strategy can add significant value when the corporation pursues related diversification (Wan et al. 2010). Highly and specific idiosyncratic factors promote resource sharing among businesses and enhance its intangible assets through internal growth. The resource-based view provides a framework to consider corporations' existing resources on which diversification is based, and the resources that are developed through diversification. In other words, corporations are motivated to pursue diversification by sharing and interconnecting resources among several business, and developing capabilities by redeploying resources among related businesses over time.

Production factors composed of tangible and intangible assets create a firm's distinct elements of value, rarity, inimitability, organization. Cooperation among stakeholders generates these tangible and intangible assets, which in turn create firm-specific assets. As corporations conduct productive activities through several stakeholders, this creates output neither separable nor individually attributable (Lan \& Heracleous 2010).

Boards of directors are positioned to allocate economic rents to important production factors as a "mediating hierarchy," while considering distinctive capabilities to create the team's assets. The board must access an array of information if it is to manage the corporate value-generating team effectively. The board's ability to access and evaluate production factors depends on board capital, mainly influenced by board composition. (Blair \& Stout 1999; Blair \& Stout 2001).

It is difficult to evaluate the quality of performance from outside. Outside directors monitor corporations and top management through output control, based on financial performance targets. They are therefore limited in their degree of control over internal corporate activities. Therefore, insiders are better place to evaluate the quality of resources inside the corporation and to allocate rent to several stakeholders. Insider directors have more information and tacit knowledge about the specific issues and problems facing the company (Osterloh \& Frey 2006), and are assumed to have the ability to judge production factors, mediate conflict, and eliminate rent-seeking among stakeholders. Additionally, insiders might make use of existing resources and stretch them to pursue other business via diversification. In this way, they pursue growth to enhance the value of resources through diversification. Insiders on a board are motivated to pursue the company's growth regardless of stockholders' concerns, emphasizing distinctive resources that are diversified into several business units.

\section{Hypothesis 2a: There is a positive association between a higher insider rate on the board of directors and the level of diversification.}

In addition, corporations should have outsider directors with different experiences and knowledge. They may provide novel and valuable viewpoints and advice to top management, and represent the external influence on the corporation. Such advice may be considered a strategic resource. Interlocking directors provide companies with high-level links with, and access to, resources in the outside environment (Barney 2002; David et al. 2010). They may hold relevant information to connect existing business to outside businesses and may influence managers to stretch beyond existing resources to enhance corporate value with their professional and personal qualifications. 
Therefore, interlocking directors are a common situation within corporations (Gabrielsson \& Huse 2005).

\section{Hypothesis 2b: A positive association exists between interlocking boards and the level of diversification.}

\section{Data and methodology}

This study uses the multivariate regression model to test the hypotheses using a sample of Japanese electronics companies for fiscal year 2013. Large corporations were chosen because their management has more discretion in deciding whether to operate as a single or diversified business compared to smaller corporations. Some corporations are predominantly occupied with electronics-related business, though are not necessarily an electronics company. To increase the number of samples, this study includes quasi-electronics industries in which the main business is machinery or devices and producing electronics materials. Most statistical data were collected from the Nikkei NEEDS Database, supplemented by the "Yuka Shoken Houkokusho" (Report on Securities and Stocks in Tokyo Stock Exchange) to collect missing data related to the variables. Corporate governance variables are collected from the Nikkei NEEDD Database, and diversification variables are obtained from the Report on Securities.

\section{Variables and measures}

This study examines the relationship between diversification and corporate governance variables. There have been many studies analyzing the relationship between strategy and diversification since Rumelt's (1974) influential research into diversification and performance. In this study, the level of corporate diversification is the dependent variable measured via a diversification index, which measures market concentration in an industrial organization. As methods to measure diversification vary, the appropriate method depends on the research model. Corporate governance studies related to diversification (Barroso, Villegas \& Pérez-Calero 2011; Chen et al. 2009; Liu \& Lai 2012) use Jacquemin and Berry's (1979) entropy model that allows a more objective separation between related and unrelated diversification drawn from information theory.

The Herfindahl-and Hirschman index (1964) is effective and easily applied to diversification research. It is normally used to measure the rate of a business's concentration rate, and can be decomposed by subtracting the concentration rate from one to obtain the extent of diversification according to the share of business in a corporation.

This study uses product diversification measured by the corporation's sales distribution across each business segment. $\mathrm{Pi}$ is the proportion of sales attributed to product segment $i$ in a corporate business. The diversification data is obtained from the notes of the financial reports or segment reporting in the annual report issued by each corporation. All data is registered in the EOL database that deals with the financial and non-financial data for Japanese corporations.

$$
\text { Diversification Index }=\left(1-\sqrt{\sum_{i=1}^{n} p_{i}^{2}}\right) \times 100
$$


There are three categories of independent variables used in this study to examine board characteristics and ownership style. The variables for board characteristics are composed of board independence and ratios of insiders on the board, and proportion of interlocking directors. Board independence is operationalized as the proportion of independent directors on the board and the proportion of interlocking directors on the board is determined by the number of directors who assume a director's position at other corporations. Interlocking directors play a role in exploring opportunities and have access to large amounts of information outside the corporation, which helps to enhance internal corporate value. Board-officer duality is a surrogate of insider directors and could influence corporations to accumulate resources, and is measured by the number of operating officers doubling as board members / the number of board members.

Ownership style consists of cross-shareholding ratio, main-bank shareholding ratio, stable shareholding ratio, and percentage of shares held by institutional investors. While the presence of foreign institutional investors is only emerging in the Japanese context, the conventional system characterized by main-bank and cross-shareholding is intact. Therefore, this study must consider the influence of cross-shareholding, main-bank shareholdings, and stable shareholding ratio on diversification strategy, in addition to the influence of foreign institutional investors. The stable shareholding ratio is cumulative percentage of stocks held by domestic companies. The crossshareholding ratio is the percentage of cross-shareholding with other publicly held companies that are permitted to hold their shares. Main-bank shareholding rate is shareholding ratio of the firm's main bank.

Institutional and foreign investors are representatives of active investors with incentives to intervene in corporate business in order to enhance shareholder value, while variables such as crossshareholding, main-bank shareholdings, and stable shareholding ratio are surrogates for silent shareholders who hold stocks to enable stability and the exclusion of external shareholders claiming shareholder profits.

The financial variables are composed of free cash flow, stock options, and the debt-equity ratio. Free cash flow describes management's discretion to use investment for their own interests, rather than considering shareholder value (Jensen 1986). The measurement captures the scenario wherein the CEO would try to diversify business for corporate needs by manipulating cash flow. The data for the free cash flow ratio follows the Nikkei Needs Cges database, as measured by free cash flow / total assets [(2nd last accounting period) $\left.{ }^{*} 100\right]$.

Stock options are often used to reduce the agency problem and resolve the conflict between management and stockholder interests, as it is assumed that these weaken management's opportunity to consume corporate resources through diversification and focus instead on using diversification to enhance shareholder value. The stock options dummy variable takes the value of 1 when stock options exist, and 0 otherwise. Corporations that use debt to fund growth will experience an increase in their debt-assets ratio (Chen et al. 2009). Diversification is associated with debt financing (Kochlar \& Hitt 1998). The debt-equity ratio is calculated by the total liabilities / total assets $\times 100$.

This study considers that company size affects the effect of several independent variables like shareholding ratio on diversification ratio. The effect of variables like shareholding ratio is 
transmitted to diversification ratio as dependent variables through company size as the mediator variable. This study defines the total asset as the company size and generates interacting variables with shareholding ratio and company size. Using interacting variables, this study can control the effect of company size on the relationship between shareholding and diversification and obtain the result considering size of corporation.

\section{Modeling}

Model 1 and Model 2 is tested with Hypothesis 1a and 2b: Whether a positive association exists between higher insider rate and level of diversification. Model 2 includes financial variables like Debt-equity ratio and stock option adoption to test the effect of debt on diversification and to infer how stock options influence managers' decision-making relating to diversification. Model 4 includes main-bank shareholding ratio to test the effect of main-bank shareholding on diversification besides cross-shareholding and stable-shareholding ratio.

In addition, Model 1 and Model 2 are used to test hypothesis $2 \mathrm{~b}$ which suppose positive association exists between interlocking boards and the level of diversification. These models include percentage of interlocking directors as independent variable. Model 3, which is used to test hypothesis $1 \mathrm{~b}$, relates the supposition that there is a negative association between board independence and level of diversification. These models include interaction variables to consider the mediated effect of company size. Interacting variables are interacted with shareholding and company size. The model includes variables relevant to the hypotheses, agency theory, and the resource-based view of the firm.

\section{a) Model 1}

Diversification ratio

$=\beta 1+\beta 2 R O A+\beta 3$ Free Cash Flow to Total assets $+\beta 4$ proportion of inside directors + $\beta 5$ Percentage of Shares held by Foreign Investors \& Corporations+ $\beta$ 6crossshareholding ratio $+\beta 7$ Company size $\times$ Percentage of Shares held by Institutional Investors $+\beta 8$ Cross-Shareholding Ratio $+\beta$ 9Company size $\times$ Cross-Shareholding ratio $+\beta 10$ Percentage of Interlocking directors $+\beta 11$ Board-Officer Duality $+\beta 12$ Ratio of insider directors $+\beta$ B13 Ratio of insider directors $+\beta 14$ Stable Shareholding Ratio $+\beta$ 15 Company size $\times$ Stable Shareholding ratio

b) Model 2

Diversification ratio

$=\beta 1+\beta 2 \mathrm{ROA}+\beta 3$ Free Cash Flow to Total assets $+\beta 4$ proportion of inside directors + $\beta 5$ Percentage of Shares held by Foreign Investors \& Corporations $+\beta$ 6crossshareholding ratio $+\beta 7$ Company size $\times$ Percentage of Shares held by Institutional Investors $+\beta 8$ Cross-Shareholding Ratio $+\beta$ 9Company size $\times$ Cross-Shareholding 
ratio $+\beta 10$ Percentage of Interlocking directors $+\beta 11$ Board-Officer Duality $+\beta 12$ Ratio of insider directors $+\beta \mathrm{B} 13$ Ratio of insider directors $+\beta 14$ Stable Shareholding Ratio $+\beta$ 15 Company size $\times$ Stable Shareholding ratio $+\beta 16$ Debt-equity ratio $+\beta 17$ Stock option adoption

c) Model 3

Diversification ratio

$=\beta 1+\beta 2 \mathrm{ROA}+\beta 3$ Free Cash Flow to Total assets $+\beta 4$ proportion of inside directors + $\beta 5$ Percentage of Shares held by Foreign Investors \& Corporations $+\beta$ 6crossshareholding ratio $+\beta 7$ Company size $\times$ Percentage of Shares held by Institutional Investors $+\beta 8$ Cross-Shareholding Ratio $+\beta 9$ Company size $\times$ Cross-Shareholding ratio $+\beta 10$ Percentage of Independent Director $+\beta 11$ Company size $\times$ Stable Shareholding ratio $+\beta 12$ Debt-equity ratio $+\beta 13$ Stock option adoption

d) Model 4

Diversification Ratio

$=\beta 1+\beta 2 R O A+\beta 3$ proportion of inside directors $+\beta 4$ Percentage of Shares held by Foreign Investors \& Corporations+ $\beta 5$ cross-shareholding ratio +6Company size $x$ Percentage of Shares held by Institutional Investors $+\beta 7$ Cross-Shareholding Ratio $+\beta$ 8 Company size $\times$ Cross-Shareholding ratio $+\beta$ 9Mainbank-shareholding ratio $+\beta$ 10Board-officer duatliy $+\beta 11$ Ratio of insider directors $+\beta 12$ stcok option adoptation 
Table 1. Descriptive Statistics

\begin{tabular}{|c|c|c|c|c|c|}
\hline & $\mathrm{N}$ & Minimum & Maximum & Mean & Std. Deviation \\
\hline ROA & 217 & $(14.98)$ & 22.15 & 4.20 & 4.42 \\
\hline ROE & 217 & (92.59) & 42.11 & 3.72 & 14.09 \\
\hline $\begin{array}{l}\text { Free Cash Flow to Total } \\
\text { Assets }\end{array}$ & 217 & $(26.14)$ & 23.94 & 0.73 & 5.55 \\
\hline $\begin{array}{l}\text { Percentage of Shares } \\
\text { held by Institutional } \\
\text { Investors }\end{array}$ & 217 & 0.00 & 66.56 & 20.49 & 17.59 \\
\hline $\begin{array}{l}\text { Company size } \times \\
\text { Percentage of Shares } \\
\text { held by Institutional } \\
\text { Investors }\end{array}$ & 217 & 0.00 & 514889926.20 & 12276876.40 & 45696223.30 \\
\hline $\begin{array}{l}\text { Percentage of } \\
\text { Shares held by } \\
\text { Foreign Investors \& } \\
\text { Corporations }\end{array}$ & 217 & 0.00 & 53.65 & 12.68 & 12.57 \\
\hline Cross-Shareholding Ratio & 217 & 0.00 & 41.48 & 10.09 & 8.15 \\
\hline $\begin{array}{l}\text { Company size } \times \text { Cross- } \\
\text { Shareholding ratio }\end{array}$ & 217 & 0.00 & 128940579.90 & 2995509.48 & 13710814.20 \\
\hline $\begin{array}{l}\text { Percentage of } \\
\text { Independent Directors: } \\
\text { Interlocking }\end{array}$ & 217 & 0.00 & 76.92 & 10.57 & 15.05 \\
\hline $\begin{array}{l}\text { Main bank-shareholding } \\
\text { ratio }\end{array}$ & 159 & 0.11 & 4.98 & 3.17 & 1.24 \\
\hline Board-Officer Duality & 217 & 0.00 & 100.00 & 64.60 & 37.09 \\
\hline Ratio of insider directors & 217 & 23.08 & 100.00 & 86.49 & 14.84 \\
\hline Stable Shareholding Ratio & 217 & 0.77 & 91.94 & 36.02 & 16.54 \\
\hline $\begin{array}{l}\text { Company size } \times \text { Stable } \\
\text { Shareholding ratio }\end{array}$ & 217 & 2828.98 & 871976951.95 & 11170974.26 & 61983663.49 \\
\hline Debt-equity ratio & 217 & 8.97 & 95.52 & 49.34 & 18.91 \\
\hline Stock options & 217 & 0.00 & 1.00 & 0.18 & 0.38 \\
\hline Valid N (listwise) & 159 & & & & \\
\hline
\end{tabular}


Table 2. Correlations

\begin{tabular}{|c|c|c|c|c|c|c|c|c|c|c|c|c|c|c|c|c|}
\hline & 1 & 2 & 3 & 4 & 5 & 6 & 7 & 8 & 9 & 10 & 11 & 12 & 13 & 14 & 15 & 16 \\
\hline ROA & 1 & & & & & & & & & & & & & & & \\
\hline ROE & $.688^{* *}$ & 1 & & & & & & & & & & & & & & \\
\hline $\begin{array}{l}\text { Percentage of } \\
\text { Shares held } \\
\text { by Institutional } \\
\text { Investors } \\
\end{array}$ & $.307^{\star *}$ & .121 & .026 & 1 & & & & & & & & & & & & \\
\hline $\begin{array}{l}\text { Company size } \times \\
\text { Percentage of } \\
\text { Shares held } \\
\text { by Institutional } \\
\text { Investors }\end{array}$ & -.041 & -.044 & .011 & $.366^{* *}$ & 1 & & & & & & & & & & & \\
\hline $\begin{array}{l}\text { Percentage of } \\
\text { Shares held by } \\
\text { Foreign Investors } \\
\text { \& Corporations }\end{array}$ & $.368^{\star \star}$ & .119 & .112 & $.896^{* *}$ & $.397^{\star *}$ & 1 & & & & & & & & & & \\
\hline $\begin{array}{l}\text { Company size } \times \\
\text { shareholding } \\
\text { Ratio }\end{array}$ & -.019 & -.024 & .050 & .065 & $.212^{\star \star}$ & .121 & $.254^{* *}$ & 1 & & & & & & & & \\
\hline $\begin{array}{l}\text { Percentage of } \\
\text { Independent } \\
\text { Directors: } \\
\text { Interlocking }\end{array}$ & .099 & .081 & .052 & $.376^{* *}$ & $.280^{\star \star}$ & $.379^{* *}$ & -.111 & .070 & 1 & & & & & & & \\
\hline $\begin{array}{l}\text { Main bank- } \\
\text { shareholding } \\
\text { ratio }\end{array}$ & -.126 & -.129 & -.100 & -.126 & -.148 & -.144 & $.468^{* *}$ & -.051 & $-.186^{*}$ & 1 & & & & & & \\
\hline Debt-equity ratio & $-.403^{* *}$ & $-.244^{* *}$ & $-.314^{* \star}$ & $-.150^{*}$ & .095 & $-.222^{* \star}$ & -.032 & .068 & $.162^{*}$ & .003 & -.050 & $-.165^{*}$ & -.085 & .112 & 1 & \\
\hline Stock options & $.142^{*}$ & .096 & .036 & $.238^{* *}$ & .040 & $.226^{* *}$ & -.073 & $.143^{*}$ & $.203^{* *}$ & -.022 & -.049 & $-.154^{*}$ & $-.150^{*}$ & .017 & .003 & 1 \\
\hline
\end{tabular}

**. Correlation is significant at the 0.01 level (2-tailed).

*. Correlation is significant at the 0.05 level (2-tailed). 
Table 3: Regression Analysis

\begin{tabular}{|c|c|c|c|c|c|c|c|}
\hline \multicolumn{2}{|c|}{ Model(1) } & \multicolumn{2}{|c|}{ Model(2) } & \multicolumn{2}{|c|}{ Model(3) } & \multicolumn{2}{|l|}{ Model(4) } \\
\hline $\begin{array}{l}\text { Standardlize } \\
\text { d Coefficient } \\
\text { (Beta) }\end{array}$ & $t$. & $\begin{array}{l}\text { Standardlize } \\
\text { d Coefficient } \\
\text { (Beta) }\end{array}$ & $t$. & $\begin{array}{l}\text { Standardlize } \\
\text { d Coefficient } \\
\text { (Beta) }\end{array}$ & $t$. & $\begin{array}{l}\text { Standardlize } \\
\text { d Coefficient } \\
\text { (Beta) }\end{array}$ & $t$. \\
\hline
\end{tabular}

\begin{tabular}{|c|c|c|c|c|c|c|c|c|}
\hline Intercept & & 5.471 & & 4.184 & & 3.864 & & 5.438 \\
\hline $\mathrm{ROA}$ & .012 & 0.109 & .035 & .320 & .028 & .257 & .135 & 1.128 \\
\hline ROE & .077 & 0.833 & .081 & .320 & .077 & .842 & .059 & .536 \\
\hline $\begin{array}{l}\text { Free Cash } \\
\text { Flow to Total } \\
\text { Asset }\end{array}$ & .103 & 1.340 & .120 & 1.548 & .114 & 1.477 & & \\
\hline $\begin{array}{l}\text { Percentage } \\
\text { of Shares } \\
\text { held } \\
\text { by } \\
\text { Institutional } \\
\text { Investors }\end{array}$ & $.344^{*}$ & 2.235 & $.354^{*}$ & 2.292 & $.314^{*}$ & 2.053 & .214 & 1.335 \\
\hline $\begin{array}{l}\text { Company } \\
\text { size } \times \\
\text { Percentage } \\
\text { of Shares } \\
\text { held } \\
\text { by } \\
\text { Institutional } \\
\text { Investors }\end{array}$ & $.197^{* *}$ & 1.242 & $.179^{*}$ & 2.371 & $.180^{*}$ & 2.400 & $.237^{\star *}$ & 2.649 \\
\hline $\begin{array}{l}\text { Percentage } \\
\text { of Shares } \\
\text { held by } \\
\text { Foreign } \\
\text { Investors \& } \\
\text { Corporations }\end{array}$ & $-.362^{*}$ & 2.622 & $-.331^{*}$ & -2.031 & $-.308^{*}$ & -1.915 & $-.361^{*}$ & -2.162 \\
\hline $\begin{array}{l}\text { Cross- } \\
\text { Shareholdin } \\
\text { g Ratio }\end{array}$ & -.114 & -1.557 & -.122 & -1.652 & $-.129-$ & -1.778 & $-.185^{\star}$ & -2.105 \\
\hline $\begin{array}{l}\text { Company } \\
\text { size } \times\end{array}$ & .148 & 1.242 & .199 & 1.612 & .208 & 1.693 & .054 & \\
\hline $\begin{array}{l}\text { Cross- } \\
\text { Shareholdin } \\
\text { g ratio }\end{array}$ & & & & & & & & .684 \\
\hline $\begin{array}{l}\text { Percentage } \\
\text { of } \\
\text { Independent } \\
\text { Directors }\end{array}$ & & & & & $.188^{*}$ & 2.492 & & \\
\hline $\begin{array}{l}\text { Percentage } \\
\text { of } \\
\text { Interlocking } \\
\text { Directors: }\end{array}$ & .017 & .245 & -.003 & -.040 & & & & \\
\hline $\begin{array}{l}\text { Mainbank- } \\
\text { shareholding } \\
\text { ratio }\end{array}$ & & & & & & & .033 & .376 \\
\hline $\begin{array}{l}\text { Board- } \\
\text { Officer } \\
\text { Duality }\end{array}$ & -.036 & -.527 & -.029 & -.426 & & & -.005 & -.061 \\
\hline $\begin{array}{l}\text { Ratio of } \\
\text { insider } \\
\text { directors }\end{array}$ & $-0.163^{*}$ & -2.225 & $-.170^{\star}$ & -2.274 & & & $-.191^{*}$ & -2.301 \\
\hline
\end{tabular}




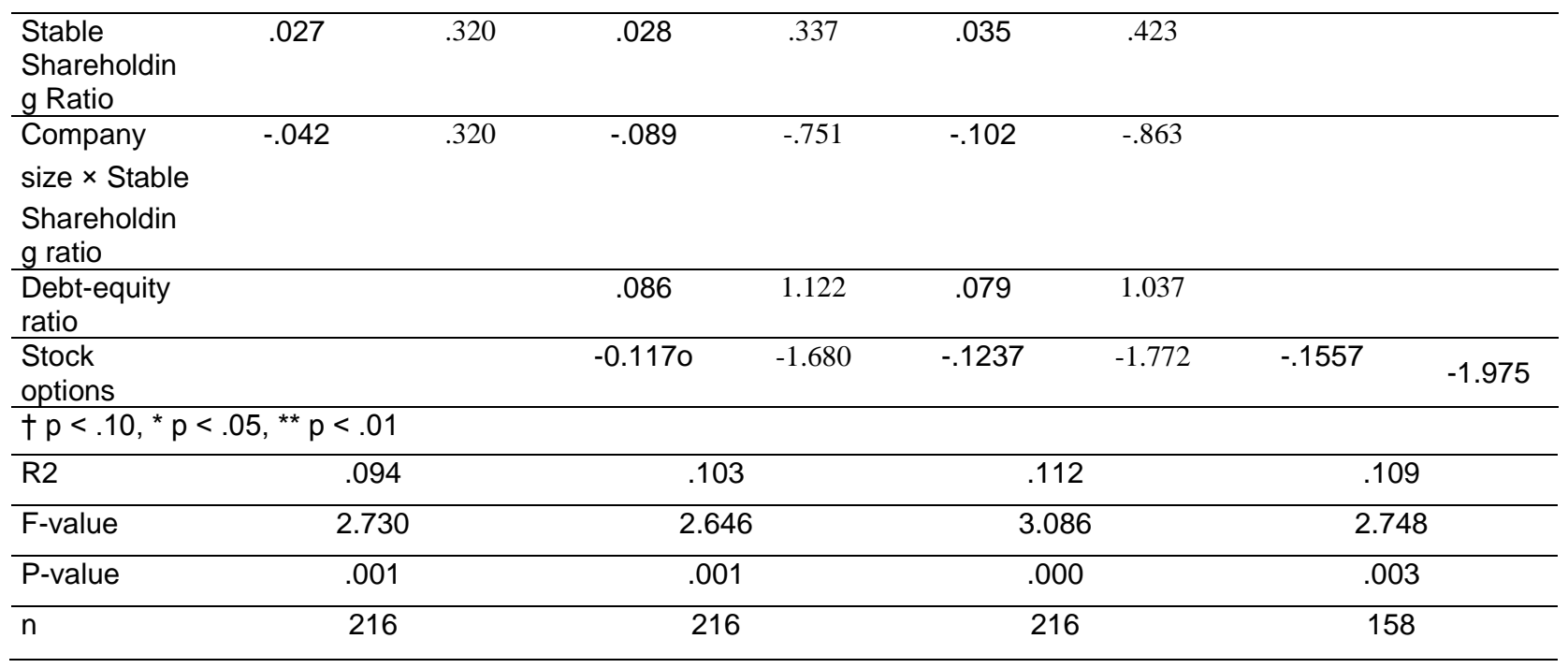

\section{Results}

Table 3 presents the results of the multivariable regression models used to test the hypotheses. Each regression model explains the causal relationship among diversification, board characteristics, and ownership style. According to Models 1-4, the institutional ownership ratio is positively associated with the ratio of diversification, mediated by company size, is positive and significant. This suggests that institutional investors prefer corporate diversification, and contrasts with the agency theory assumptions that emphasize that owners prefer a focus on core business. The association between cross-shareholdings and diversification is not significant, while foreign stockholding is negatively associated with diversification. Though this study cannot confirm how cross-shareholding is related to diversification, foreign shareholding is negatively associated with diversification. Foreign shareholdings, including foreign institutional investors, has a negative effect on diversification, and motivates managers to focus on existed business, which suggests that foreign investors motivate managers to focus on existing business to pursue efficient asset allocation and to make it easier to evaluate corporate value. In this case, foreign ownership means ownership by foreign industries and investors, who control asset allocation to focus on existing business and do not prefer to diversify business. The results show that there is a partially negative association between board independence and level of diversification, partially supporting hypothesis 1a. This hypothesis holds for foreign owners, and not institutional investors predominately made up of Japanese financial institutions or institutional investors. Additionally, cross-shareholding among corporations is negatively associated with diversification, suggesting that corporations linked with cross-shareholding or a business group prefer to avoid diversification in favor of focusing on existing business.

According to Models 1 and 2, the regression results show that insider boards are negatively associated with diversification, while the results from Model 3 demonstrate that independent boards are positively associated with diversification. Hypothesis $2 \mathrm{a}$, which proposes a positive association between higher insider rates and the level of diversification, is not supported. This also runs counter to the assumptions of agency theory that insiders on the board and top management in corporations 
diversify corporate business to strengthen their own power and entrench their positions, suggesting that insider-dominant boards focus on existing business and do not seek diversification to strengthen their own positions. David et al. (2010) showed that insider-dominant boards prefer corporate growth over pursuing profit, and such a board is assumed to explore opportunities to broaden the business. However, contrary to that study, this study revealed that boards composed of insiders avoid the risks associated with diversification and focus on businesses based on the company's core business and competencies.

Model1,Model2 shows that the relationship between the ratio of interlocking directors and diversification is not significant. Hypothesis $2 \mathrm{~b}$, which proposes a positive association between interlocking boards and the level of diversification, is not supported.

\section{Discussion}

I investigated how ownership style and board composition influences diversification in Japanese corporations based on agency theory and the resource-based view of the firm. The regression analysis results from this study partially substantiate agency theory, which proposes that institutional owners are hesitant to diversify, and independent directors inhibit diversification to protect stockholder value.

The results show that the relationship between diversification and the ratio of shares held by institutional investors is positive, while there is a negative association between diversification and the ratio of foreign stockholding. Institutional investors are motivated to monitor corporate management. As the ratio of their stockholdings increase, corporations are pressured to accept monitoring from the stock market. In this study, the ratio of shares held by institutional investors includes foreign investors, shares held by Trust, and shares held by Special Accounts in insurance companies. This study finds that the ratio of institutional investors is positively related to diversification, while the ratio of foreign investors is negatively associated with diversification. Foreign investors encourage management to focus on core business in preference to diversification. Though institutional investors includes some foreign investors, which are excluded in the ratio of foreign investors in this study, Japanese institutional investors, including financial institutions such as trust accounts and insurance companies, may support corporate diversification that increases the risk of inefficient asset allocation and decreased power and ability to monitor the company and determine corporate value.

This can be interpreted in two ways. First, institutional investors have a favorable attitude toward corporate managers and try to collaborate with them so long as their business is anticipated to make profits. Second, it would be expected that diversified business could be profitable and relevant to core business. That is, the diversification strategy is not for the purpose of risk management or the entrenchment of managers' positions, but motivated by profit. Owners and investors normally do not prefer diversification because they have already diversified risk through their investment portfolio.

In line with these results regarding ownership, the ratio of independent directors is positively associated with diversification, while the ratio of insider directors is negatively related to diversification. In terms of the relationship between the ratio of independent directors and 
diversification, the results imply that increasing independent outsiders in the boardroom is an effective means to avoid unnecessary diversification and solve the agency problem, and are consistent with results from Anderson et al. (2000) and Coles et al. (2005). They revealed that diversified corporations adopt more independent directors to improve monitoring because diversified businesses are more complex and require more directors to interpret and audit the business. It can be also inferred that independent outsiders are expected to bring resources and competencies into the firm through their advisory and counseling functions, and are assumed to reduce the risk of an ingrained view of the business by bringing in an outside viewpoint (Gabrielsson and Huse, 2005), consistent with the resource-based view.

On the other hand, According to agency theory, inside directors and CEOs pursue diversification for corporate growth in order to secure their employment and interests, which is not necessarily linked to shareholders' interests. However, the results suggest that insiders tend to focus on core business and are not so motivated to diversify their own business. Accordingly, this study finds a significant and positive association between diversification and the cross-shareholding ratio.

In Japan, inside directors are less active in monitoring and intervening in the business while they are subordinate to CEO. On the other hand, insiders are employees who are promoted from lower positions and account for employees' stakes. In the current Japanese business environment, corporations tend to pursue a focused strategy and concentrate on profitable business, rather than diversify. The data used in this study is from 2012-2013, and the corporate governance data reflects the recession before 2012 when the Japanese economy recovered. The descriptive statistics show Japanese boardrooms are composed predominantly by insiders compared to independent directors. Insiders avoid the risk of diversification and focus on core business to enhance corporate value. Though the results in this study do not support hypotheses $2 \mathrm{a}$ and $2 \mathrm{~b}$, and the resourcebased view seems not to apply, there is actually evidence to suggest that corporate governance intervenes in strategic management. It can be inferred from these results that corporate boards take the role of a steward to generate value in a corporation. In addition, I argue that corporate boards can evaluate the quality of resources and allocate rents inside the corporation, as boards promote the use of idiosyncratic resources because the strategic choice between focus and selection of business is the foremost issue for Japanese firms aiming to improve their performance.

\section{Implications and Conclusion}

Many Japanese electronics corporations are currently undertaking corporate governance reforms while developing their focus and choice of existing businesses. Though the hypotheses abstracted from agency theory and resource based view were not supported, I insist that the relationship among diversification and ownership and board composition is reflected by the current strategic tendency in Japanese corporations.

Academically, this study implies that increasing independent directors is an effective means to reduce the agency cost between principals and agents during diversification. It leads to an enhanced monitoring ability of the board to review the business management for stockholders' interest. Additionally, increasing independent directors should bring different perspective to the corporation, enhancing the organization's resources and generating distinctive capabilities. 
The implications for practitioners mirror those for academics. Placing more independent directors in the boardroom can prevent a corporation from consuming cash flow and wastefully allocating corporate rents. The enhanced monitoring ability should lead to appropriate asset allocations. Both diversification and increasing the number of independent outsiders on the board bring different views, stimulating creating thinking and innovative ideas in terms of corporate strategy.

This study found a possible connection between the corporate governance system and strategic management, and demonstrated the relationship between board composition and diversification strategy in Japanese electronic corporations. Additionally, strategy and corporate governance seem to have different relationships in different country and cultural contexts.

These results are subject to limitations in terms of construct validity and generalizability. Firstly, the concept of diversification should be categorized according to product and geography. This study does not differentiate between related and unrelated diversification. Secondly, this study could not identify the association between financial performance (ROA or Tobin's Q), board composition, and diversification. More samples and data points are required in order to explore this problem, which should be applied to a conceptually appropriate model. Future research should examine the associations among these factors with a strict categorization of corporate diversification.

\section{References}

Aoki, M, Jackson, G \& Miyajima, H 2007, Corporate Governance in Japan: Institutional change and organizational diversity, Oxford University Press.

Anderson, R, Bates, T, Bizjak, J \& Lemmon, M 2000, "Corporate governance and firm diversification", Financial Management 21, 5-22.

Barroso, C, Villegas, MM \& Pérez-Calero, L 2011, "Board influence on a firm's internationalization", Corporate Governance: An International Review, vol. 19, no. 4, pp. 351-67.

Barney, JB 2002, Gaining and sustaining competitive advantage, Prentice-Hall, Englewood Cliffs, NJ.

Blair, MM \& Stout, LA 1999, "A team production theory of corporate law", Virginia Law Review, vol. 85, pp. 247-328.

Blair, MM \& Stout, LA 2001, "Corporate accountability: Director accountability and the mediating role of the corporate board", Washington University Law Review, vol. 79, pp. 403-47.

Chen, R, Dyball, MC \& Wright, S 2009, "The Link Between Board Composition and. Corporate Diversification in Australian Corporations", Corporate Governance: An International Review, vol. 17, no. 2, pp. 20828.

Choi, SB, Park, BI \& Hong, P 2012, "Does Ownership Structure Matter for Firm Technological Innovation Performance? The Case of Korean Firms", Corporate Governance: An International Review, vol. 20, no. 3, pp. 267-88.

Colpan, AM, Yoshikawa, T, Hikino, T \& Del Brio, EB 2011, "Shareholder Heterogeneity and Conflicting Goals: Strategic Investments in the Japanese Electronics Industry", Journal of Management Studies, vol. 48, no. 3, pp. 591-618.

Coff, RW 2010, "The coevolution of rent appropriation and capability development", Strategic Management Journal, vol. 31, no. 7, pp. 711-33. 
Coles, J, Daniel, N \& Naveen, L 2005. Boards: does one size fit all? Arizona State University Working Paper.

Dalziel, T, Gentry, R \& Bowerman, M 2011, "An Integrated Agency-Resource Dependence View of the Influence of Directors' Human and Relational Capital on Firms' R\&D spending", Journal of Management Studies, vol. 48, no. 6, pp. 1217-42.

David, P, O'Brien, JP \& Yoshikawa, T 2008, “The Implications of Debt Heterogeneity for R\&D Investment and Firm Performance", Academy of Management Journal, vol. 51, no. 1, pp. 165-81.

David, P, O'Brien, JP, Yoshikawa, T \& Delios, A 2010, "Do shareholders or stakeholders appropriate the rents from corporate diversification? The influence of ownership structure", Academy of Management Journal, vol. 53, no. 3, pp. 636-54.

David, P, Yoshikawa, T, Chari, MD \& Rasheed, AA 2006, "Strategic investments in Japanese corporations: do foreign portfolio owners foster underinvestment or appropriate investment?", Strategic Management Journal, vol. 27, no. 6, pp. 591-60.

Eisenhardt, KM 1989, "Building theories from case study research", Academy of Management Review, vol. 14 , no. 4 , pp. 532-50.

Gabrielsson, J \& Huse, M 2005, "Outside directors in SME boards: A call for theoretical reflections", Corporate board: Role, duty and composition, vol. 1, no. 1, pp. 28-37.

Jacquemin, AP \& Berry, CH 1979, "Entropy measure of diversification and corporate growth", Journal of Industrial Economics, vol. 27, pp. 359-69.

Jensen, MC 1986, "Agency costs of free cash flow, corporate finance, and takeovers", American Economic Review, vol. 76, no. 2, pp. 323-29.

Jensen, MC 1989, "The eclipse of the public corporation”, Harvard Business Review, vol. 67, pp. 61-74.

Hirshman, AO 1964, "The Paternity of an Index", The American Economic Review, Vol. 54, No. 5, p. 761.

Kiel, GC \& Nicholson, GJ 2003, "Board Composition and Corporate Performance: how the Australian experience informs contrasting theories of corporate governance", Corporate Governance: An International Review, vol. 11, no. 3, pp. 189-205.

Kochhar, R and Hitt, M 1998, "Linking corporate strategy to capital structure: diversification strategy, type and source of financing", Strategic Management Journal, Vol. 19, 1998, pp. 601-610.

Lan, LL \& Heracleous, L 2010. Rethinking agency theory: The view from law. Academy of Management Review, 35 (2): 294-314.

Lee, M, Son, B \& Om, K 1996, "Evaluation of national R\&D projects in Korea", Research Policy, vol. 25, no. 5, pp. 805-18.

Liu, CL \& Lai, SM 2012, "Organizational complexity and auditor quality", Corporate Governance: An International Review, vol. 20, no. 4, pp. 352-68.

Marris, RL 1964, The Economic Theory of Managerial Capitalism, MacMillan, London.

Machold, S, Huse, M, Minichilli, A \& Nordqvist, M 2011, "Board leadership and strategy involvement in small firms: A team production approach", Corporate Governance: An International Review, vol. 19, no. 4, pp. 368-83.

May, DO 1995, "Do managerial motives influence firm risk reduction strategies?", The Journal of Finance, vol. 50 , no. 4 , pp. $1291-1308$. 
Nakano, M \& Nguyen, P 2012, "Board Size and Corporate Risk Taking: Further Evidence from Japan", Corporate Governance: An International Review, vol. 20, no. 4, pp. 369-87.

Nakano, M \& Nguyen, P 2013, "Foreign ownership and firm performance: evidence from Japan's electronics industry", Applied Financial Economics, vol. 23, no. 1, pp. 41-50.

Nicholson, GJ \& Kiel, GC 2007, "Can Directors Impact Performance?: A case-based test of three theories of corporate governance", Corporate Governance: An International Review, vol. 15, no. 4, pp. 585-608.

Osterloh, M \& Frey, B 2006. "Shareholders Should Welcome Knowledge Workers as Directors", Journal of Management and Governance, vol. 10, no. 3, pp. 325-334.

Rumelt, RP 1974. Strategy, structure and economic performance. Cambridge, MA: Harvard University

Tribo, JA, Berrone, P \& Surroca, J 2007, "Do the type and number of blockholders influence R\&D investments? New evidence from Spain”, Corporate Governance: An International Review, vol. 15, no. 5, pp. 828-42.

Yoshikawa, T \& Phan, PH 2005, The Effects of Ownership and Capital Structure on Board Composition and Strategic Diversification in Japanese Corporations, Corporate Governance: An International Review, vol. 13, no. 2, pp. 303-312.

Wan, WP, Hoskisson, RE, Short, JC \& Yiu, DW 2010, "Resource-based theory and corporate diversification: Accomplishments and opportunities", Journal of Management, vol. 37, no. 5, pp. 1335-68.

Yoshikawa, T, Tsui-Auch, LS \& McGuire, J 2007, "Corporate governance reform as institutional innovation: The case of Japan", Organization Science, vol. 18, no. 6, pp. 973-88. 